Ante Rončević

University North

Department of Economics

48000 Koprivnica, Croatia

aroncevic@unin.hr

Ana Globočnik Žunac

University North

Department of Economics

48000 Koprivnica, Croatia

agzunac@unin.hr
Martina Car

Youth Center Križevci

48260 Križevci, Croatia

martina.car@cmk.hr
JEL: Z1

Preliminary communication

https://doi.org/10.51680/ev.34.1.12

Received: April 22, 2020

Revision received: September 9, 2020

Accepted for publishing: September 25, 2020

This work is licensed under a

Creative Commons Attribution-

NonCommercial-NoDerivatives 4.0 International License

\title{
INTERCULTURAL DIFFERENCES BETWEEN AUSTRIA AND CROATIA IN THE CONTEXT OF BUSINESS COMMUNICATION
}

\begin{abstract}
Purpose: The globalization of economy in the context of adaptation and successful communication within the EU emphasizes the importance of perceiving and adapting to intercultural diversity in order to achieve business success. This paper analyzes the notion of interculturalism from the aspect of observing business relations. It emphasizes the perception of intercultural outcomes of business cooperation. In the focus were specific characteristics of Croatia and Austria, countries geographically close, but with many diversities.
\end{abstract}

Methodology: The research tasks were to determine the phenomena of business intercultural interaction, obstacles in intercultural communication and the dimensions of cultural values according to Hofstede. Respondents' attitudes were examined by a survey containing 18 statements. The respondents had experience in Croatian-Austrian intercultural business relations. Three hypotheses were formulated following the idea that even though the two countries share a part of history and have built rich cooperation, there are significant differences that may be of importance for business communication.

Results: The first hypothesis suggested higher business formality in the Austrian culture, whereas results show that the attitude towards formality is equal. The Croatian culture lacks intercultural experience, which makes it less adaptable. Equality in gender relations was confirmed. These limitations mostly apply to a small sample showing small differences as it is a preliminary study.

Conclusion: The research provides a foundation for a broader and deeper survey that will provide guidelines for understanding intercultural communication and its rules.

Keywords: Cultural intelligence, intercultural communication, cross-cultural business, international business, cultural diversity, cultural characteristics

\section{Introduction}

A good knowledge of business management in different cultures is essential for all those who want to do business or who find themselves in an international environment. The great differences that exist in business management and business in different cultures are conditioned by the different historical, political, economic and cultural circumstances of the development of particular countries (Bedeković \& Golub, 2011). The knowledge and understanding 
of such circumstances and customs is a prerequisite for successful communication, which is essential for achieving business results. Communication is described in three dimensions: content, form and purpose (Čerepinko, 2012). The target may be the person himself, another person in interpersonal communication, or another entity such as a group, organization or society. Business communication should be viewed from the perspective of two functions (Edwards, 1985): personal, which denotes belonging to social groups, personal style and attitudes towards the act of communication or content of the message, and interpersonal characterizing relationships among participants in the communication process, social roles and shared knowledge. Social conditionality links communication with the specificities of a particular culture. Edward Burnett Tylor, a British anthropologist, defined culture as a complex entity that includes knowledge, beliefs, art, law, customs and any other abilities and habits acquired by a person as a member of the community (Schneider-Flaig, 2010). For the GLOBE project, culture is shared motives, values, beliefs, identities, and interpretations of significant events arising from the shared experiences of members of the collective that are passed down through generations (Osredečki, 2007). It follows from both definitions that culture is flexible and adaptable, and that individuals can easily adapt to different situations, which is very important in the context of business. Interculturalism in business, as a dynamic process, implies a relationship, that is, interaction, exchange and perspective characterized by the encounters of culturally diverse individuals based on the plurality of relationships with a pronounced openness and social dimension of intercultural dialogue (Samovar et al., 2013). The importance of understanding culture in business communication processes has led to the definition of intercultural management, a specific area of management that deals with issues of mutual relations and interaction of members of different cultures in establishing communication aimed at effective cooperation and achieving business success in the international global market (Zakić \& Milutinović, 2013). Skilled communication management within intercultural management requires cultural intelligence, which involves the broad mindset and skill of understanding a particular culture, knowledge of culture through personal interaction, gradually changing one's thinking toward a better understanding of a given culture, and improving behavior in order to be more relevant in interacting with members of the culture. Accordingly, cultural intelligence includes three parts (Osredečki, 2007): knowledge of culture and how it influences behavior, awareness of cultural diversity, and cross-cultural skills that enable one to interact with people from different cultures. Kumbier and von Thun (2009) consider that cross-cultural risk is a common occurrence in international business given the diverse cultural heritage of participants. Cross-cultural risk is defined as a condition and event in which inadequate cultural communication puts at stake one of the fundamental values of a particular national culture (Bedeković, 2010). Lewicki et al. (2006) outline three ways of dealing with cultural differences: expecting others to adapt to us, "be like me" (mimicking people's habits), understanding cultural differences, and developing cultural intelligence, which is a prerequisite for getting to know yourself and your own culture. By doing so, one must become aware of the values, attitudes, and perceptions of one's own culture, because everyone sees the world through the prism of own culture (Kroeber \& Kluckhohn, 1952).

\section{Previous studies on cultural diversity}

The most significant name in contemporary literature is Hofstede (1980), who defines culture as a value system that distinguishes members of one group from another, influencing their behaviors in a systematic and predictable way. In accordance with individual cultural dimensions, nations and individuals develop specific competences and ways of working in accordance with their values and environment (Tomljenović \& Stilin, 2012). In the context of entrepreneurship, for example, national culture will influence the formation of individual cognitive schemas, and thus the relationship to risk-taking and start-ups. The research model developed by Hofstede is best known and includes a comparison of the following dimensions (Rahimić \& Podrug, 2012): power distance, uncertainty avoidance, individualism/collectivism, masculinity/femininity, and long-term/short-term orientation. These dimensions are a kind of framework for defining how organizations are structured, influencing employee motivation, and addressing the various issues and problems encountered by people and organizations within different societies. Individualism and collectivism speak of the strength of the bonds between individuals, that is, the cohesiveness of social groups. 
Individualistic cultures emphasize personal initiative and achievement as basic social values,, while collectivistic ones emphasize belonging to social groups and the superiority of the group over the individual. People in an individualistic culture are happy to make their own decisions or only with close friends; they are interested in the final result of an act on themselves; the members are perceived as independent individuals (Mesić, 2006). Hofsted calls 'masculine cultures' those that strive to differentiate gender roles. Cultures that give greater value to masculine traits emphasize assertiveness, competitiveness, and material success, while feminine cultures are those that allow greater overlap in the social roles of both genders. Cultures that attach great value to feminine characteristics emphasize quality of life, interpersonal relationships, and caring for the weak.

Power distance refers to the degree of inequality in the distribution of power among people, which is held to be normal and acceptable in a society and then in the organizations operating within the culture. In cultures with high power distance, children are expected to be obedient to their parents and are not treated more or less as equals (Samovar et al., 2013). Furthermore, people are expected to show respect for persons of higher status. Power distance also refers to the extent to which power, prestige and wealth are distributed within a single culture. Cultures with high power distance have power and influence concentrated in the hands of the few, not throughout the population. These countries are usually more authoritarian and communication can be such as to limit interaction and amplify differences between people. At work, superiors and subordinates are considered to be existentially unequal. Power is centralized and there is a big pay gap between the top and bottom of the organization.

Uncertainty avoidance refers to the degree of vulnerability of members of a culture in unclear and unfamiliar situations and is related to the need for predictability, that is, written/unwritten rules. In the business world, this dimension is particularly relevant to the relation towards the risk, the level of ambition, and tolerance for ambiguity. Cultures with a with a high level of uncertainty avoidance are active, aggressive, emotional, compulsive, seeking safety and less tolerant to risk raking. Cultures with low uncertainty avoidance are less aggressive, not emotional, relaxed, accept personal risk, and are relatively tolerant (Bedeković \& Golub, 2011).

\subsection{Characteristics of Austrian business culture}

Austria is an individualistic country, where each employee is valued in proportion to their own work results, emphasis is placed on family values and privacy, and all levels of management participate in the negotiation process (Jariya, 2012). Austria has the lowest power distance when compared to the Western European countries that are members of the European Union. Despite this, certain Austrian companies are more hierarchically organized and one key person, after consulting their associates, is in charge of reaching a final decision in the negotiations. Austrian business people are conservative, humble, formal and well organized. They take their business seriously and the first impression will be mostly influenced by the appearance and manners of the new business partner. Austrians appreciate accuracy, orderliness and compliance with the rules in private and business terms and expect business partners to behave in accordance with the Austrian values, starting with the way they dress to the way they communicate in business meetings (Perlitz \& Seger, 2004). Austria is a very homogeneous country, especially from a business point of view. Despite its development, Austria has maintained a conservative approach to business in which tradition plays a very important role. Although the official language is German, the dialect spoken by Austrians is quite different from standard German, so that first contacts will require some 'habituation' to the Austrian dialect (Jariya, 2012). Austrians pay special attention to the organization and plan meetings in advance, even for months. Business clothes play an important role in making a first impression, but also in creating an opinion on the style of business partners. They like simple and elegant lines of business attire. In each case suits should be of neutral colors (gray, black, brown, dark blue) without additional color (Oyserman et al., 2002). Any fashion accessories, such as ties for men or jewelry for women, should have a moderate dose of style and color and should not be over-emphasized. Business partners may appear in traditional Austrian clothing, which is of particular value to them. Sometimes these are just details (embroideries) on the collar of a coat, but sometimes they can also be traditional "Lederhosen" for men or "Dirndl" dress for women (Rammer, 2016). In Austria, meetings are arranged between 10 am and $1 \mathrm{pm}$ and between $3 \mathrm{pm}$ and $5 \mathrm{pm}$. Accuracy is a significant feature, so arriving on time, fulfilling commitments on time, planning on time, adhering to all deadlines are important preconditions for successful cooperation. Staying in office longer than regular working hours too fre- 
quently can be interpreted as being ineffective at work. In business talks and negotiations, a business partner is expected to say what they think and not promise things they cannot accomplish. Although Austrians love humor, it should be avoided at business meetings, especially at first contacts, because Austrians take them very seriously and behave accordingly (Oyserman et al., 2002). Late arrivals are not tolerated and reflect a lack of respect for business partners. Status and hierarchy are important organizational aspects in Austrian companies. Very often, managers and executives refer to a person by position in the company, not a surname. The reason for thorough preparation for the negotiation process is that Austrians are not prone to business risk and unforeseen situations, and once they agree on the final decision, it is difficult to change their minds. Also, Austrian business people are long-term oriented to work, but also to maintaining good relations with business partners. Austria is characterized by a 'male' type of negotiation in terms of assertiveness, ambition, desire to prove and succeed (Rammer, 2016).

\subsection{Characteristics of Croatian business culture}

In researching Croatian business culture, it should be noted at the outset that not many relevant scientific studies have been found that would provide such specific guidance as in the example of Austrian culture described above. Croatians are known for their relaxed attitude towards business, although they maintain a high level of professionalism and are considered traditional. In Croatia, in first business contacts, there is the proper way to make introductions. In an equal business position, or in cases where there is no big difference, the younger person is introduced to the older one and the man is to be introduced to the woman. On the other hand, a person junior by rank is introduced to the person in senior position (regardless of age and gender) (Mikolić, 2002). Croatians in general, and thus also in the business context, are considered to be good hosts. The role of the host is to entertain guests, provide a comfortable atmosphere, lead the conversation while making sure no one is neglected (Poslovni savjetnik, 2006).

\section{Research methodology}

From the stated theory in the previous part of this paper the question arises about the level of cultural intelligence of employees. It is important to find the answer about cultural intelligence within in- tercultural business management in Croatia as well as about cultural intelligence of the general population. Given the lack of data based on scientific research, our intention was to answer only some basic questions in order to raise awareness of one's own cultural features and to compare the features of Croatian and Austrian cultures in terms of geographical proximity and frequency of business relations. Three hypotheses were set at the beginning of the research:

H1: Austria is less tolerant of informality and relaxed attitudes in business than Croatia (e.g. late arrivals to meetings, ignorance of the customs of other cultures, etc.).

$\mathrm{H} 2$ : Croatians have less contact with people from different cultures than Austrians because Austria is more heterogeneous than Croatia and for that reason Austrians adapt to other cultures more easily.

H3: Croatians as well as Austrians find no difference in the reliability of women in business compared with men.

The survey was conducted by interviewing the respondents using a structured questionnaire with a total of 18 statements with which the respondents were asked to determine the level of agreement on a five-point Likert scale based on their own experience. The identical questionnaire, only in different languages, was used to conduct the survey in Croatia and Austria.

A total of 80 respondents completed the survey, of which 50\% were from Croatia and the other 50\% were from Austria. A survey conducted in Croatia was completed by $75 \%$ of women and $25 \%$ of men, while a survey conducted in Austria was completed by $80 \%$ of women and $20 \%$ of men. The Croatian survey was completed by $37.5 \%$ of respondents with high school education, $32.5 \%$ with completed undergraduate and $30 \%$ with completed graduate education. In Austria, there were $40 \%$ of respondents with high school education, $33.3 \%$ with completed undergraduate and $26.7 \%$ with completed graduate education. When asked how many languages they speak, $60 \%$ of Croatian respondents answered that they speak two languages, $31.4 \%$ speak three languages, and $8.6 \%$ speak only one foreign language. As for Austrians, $72.7 \%$ speak two languages and $27.3 \%$ speak three languages. 


\section{Results}

According to the research results, $52.5 \%$ of Croatian respondents (Graph 1) would not tolerate arriving late under any circumstances, $45 \%$ of them would tolerate it in case it is up to 15 minutes, and the rest of $2.5 \%$ would even tolerate being late up to 30 minutes. Though the percentages are almost

\section{Graphs 1 and 2 Tolerance of late arrivals}

Graph 1 Croatia

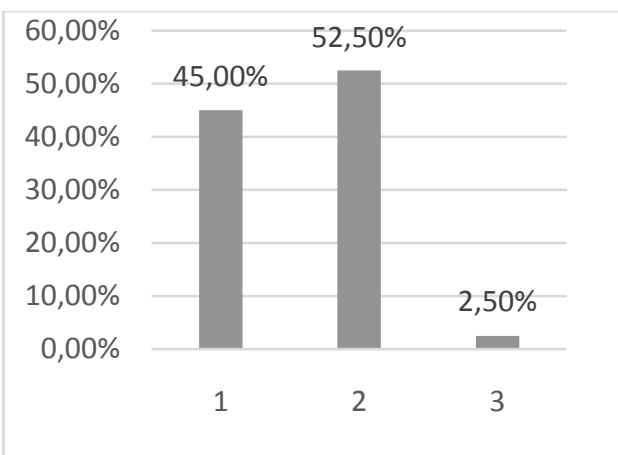

the same, e.g. $53.3 \%$ of the Austrian respondents would not tolerate late arrivals (Graph 2), there is none among Austrians who would tolerate being late up to 30 minutes. Accordingly, there is $46.7 \%$ of respondents who would tolerate being late up to 15 minutes. There were no respondents in both cultures who would tolerate delays that exceed 30 minutes.

Note: 1 - Yes, in case it is up to 15 minutes 2 - I do not tolerate in any circumstances 3 - Yes, I would tolerate up to 30 minutes Source: Authors

As Graph 3 shows, there are $52.5 \%$ of Croats who think that it is necessary to get informed about the culture of the business partner before starting the cooperation. There are $35 \%$ of respondents in Croatia who agree with this, but not completely and
$10 \%$ who have no opinion about the subject. The remaining percentage of respondents, $12.5 \%$ of them, do not agree with the statement about the importance of learning about the partner's culture prior to starting business cooperation.

\section{Graphs 3 and 4 Attitude towards the importance of studying cultural specifics prior to business coop- eration}

Graph 3 Croatia

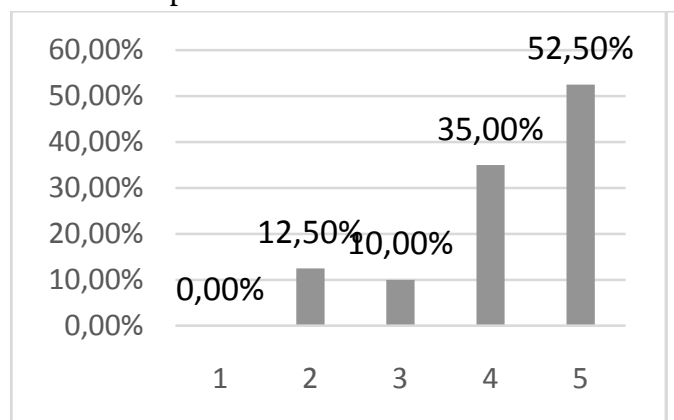

Graph 4 Austria

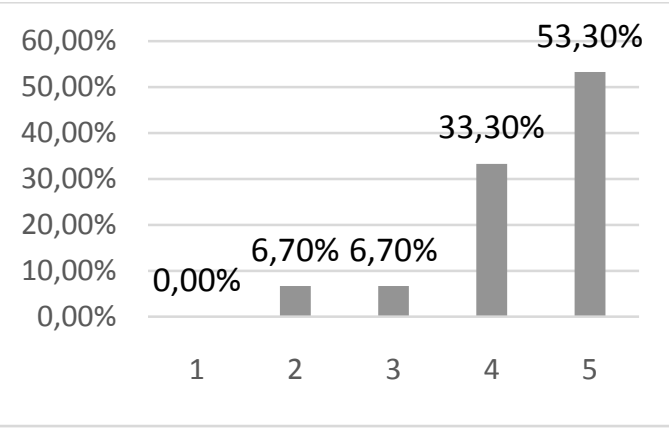

Note: 1 - I completely disagree 2 - I disagree 3 -I have no opinion about the subject 4 - I agree 5 - I completely agree Source: Authors 
The total of $53.3 \%$ of Austrian respondents (Graph 4) completely agree with the statement about the attitude towards the importance of studying cultural specifics prior to business cooperation, and $33.3 \%$ of them agree with the stated importance.
Among Austrians only 6.7\% of respondents have no specific opinion on the subject and there are $6.7 \%$ of respondents who find it unimportant to study the culture of the business partners before starting cooperation.

\section{Graphs 5 and 6 I feel offended if a business partner does not adapt to my culture}

Graph 5 Croatia

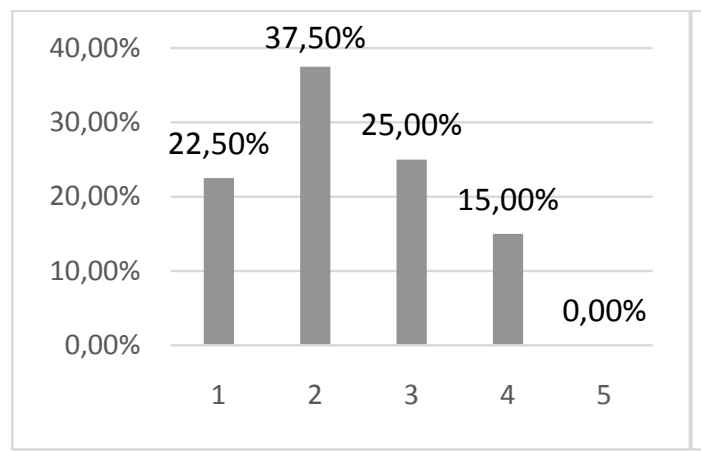

Graph 6 Austria

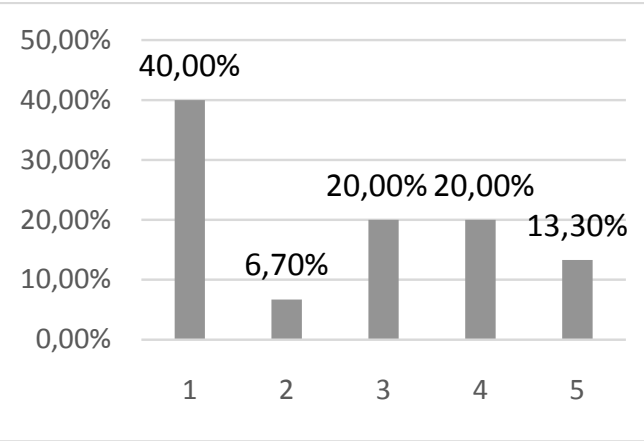

Note: 1 - I completely disagree 2 - I disagree 3 - I have no opinion about the subject 4 - I agree 5 - I completely agree Source: Authors

When asked if they feel offended if a business partner does not adapt to their culture, Croatian respondents (Graph 5) answered as follows: $22.5 \%$ completely disagree and additional $37.5 \%$ do not agree. There is $25 \%$ of respondents in Croatia without any opinion on the subject while only $22.5 \%$ of them agree with the statement. Austrian respond- ents (Graph 6) for the same question gave slightly different answers. There are $20 \%$ of Austrians without an opinion and $33.3 \%$ of those who agree with the statement. $40 \%$ completely disagree, which is a significantly big percentage, while another $6.7 \%$ disagree and show that they do not feel offended in such circumstances.

\section{Graphs 7 and 8 Use of titles in business communication}

\section{Graph 7 Croatia}

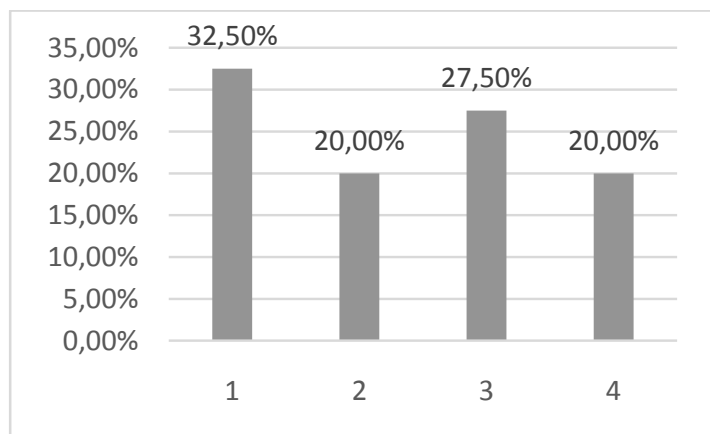

Graph 8 Austria

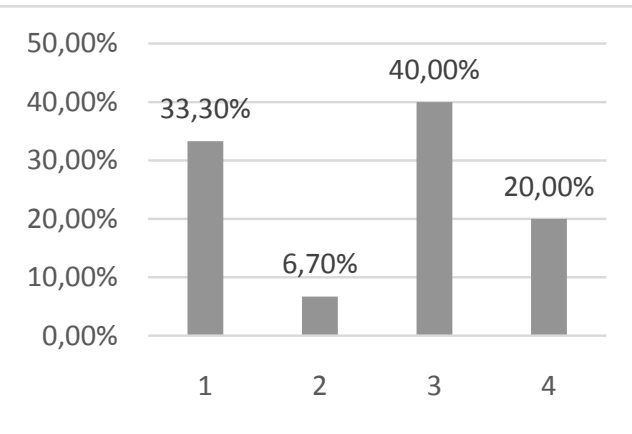

Note: 1 - Always 2 - Often 3 - Rarely 4 - Never

Source: Authors 
Croats (Graph 7) use professional or other titles in business communication more often than Austrian respondents (Graph 8). While 32.5\% use them always, there are $20 \%$ who use titles often. In total $40 \%$ of Austrians use them always or often. The same percentage, $20 \%$ of respondents from both cultures never use titles in business communication. In Croatia $27.5 \%$ and $40 \%$ in Austria use them rarely.

\section{Graphs 9 and 10 Cultural differences influence business relations}

Graph 9 Croatia



Note: 1 - I completely disagree 2 - I disagree 3 - I have no opinion about the subject 4 - I agree 5 - I completely agree Source: Authors

When asked about the influence of cultural differences on business relations, Croatians (Graph 9) believe these differences affect business in a greater percentage than those with the opposite opinion. In total $57.5 \%$ of respondents agree or completely agree with this statement while only $40 \%$ complete- ly disagree. Austrian respondents (Graph 10) show in greater percentage $(20 \%)$ indeciseveness, i.e. they have no opinion. In total $40 \%$ of Austrians disagree or completely disagree while the same percentage (smaller than the Croatian) agrees or completely agrees with the statement.

\section{Graphs 11 and 12 Gender equality with regard to reliability in business}

\section{Graph 11 Croatia}

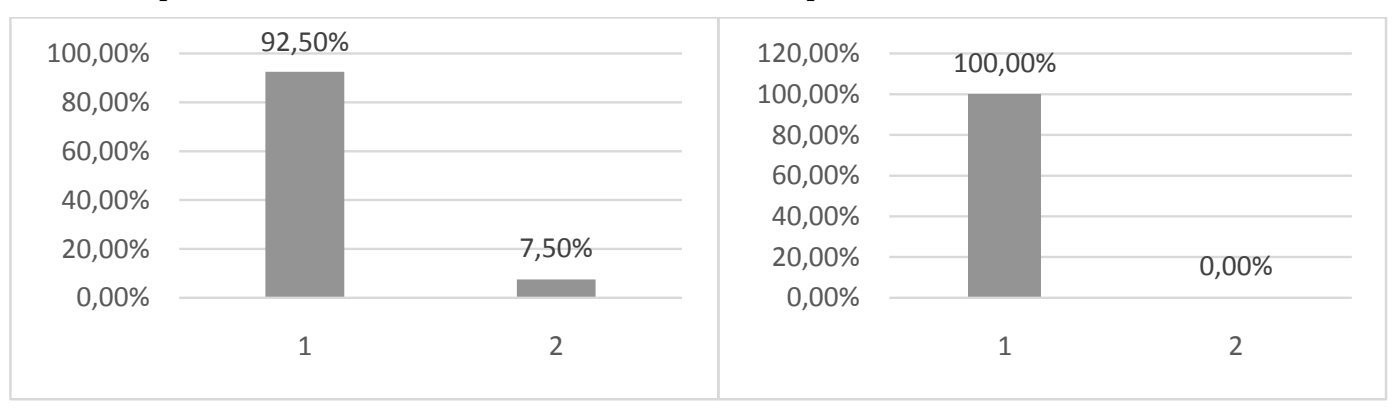

Note: 1 - Yes 2 - No

Source: Authors

Respondents from Croatia (Graph 11) and Austria (Graph 12) show very similar results when asked about equality of gender with regard to reliability in business. The difference can be noticed in the result 
that in Austria no respondents see any difference between the genders, while $7.5 \%$ of Croatians think that men and women are not equally reliable when it comes to business.
The results show that more respondents in Croatia (Graph 13) have male superiors at work (55\%) while there is $10 \%$ less of female superiors. The difference in Austria (Graph 14) is slightly bigger as there are $60 \%$ of male superiors and $20 \%$ of females.

\section{Graphs 13 and 14 Gender of the respondent's superior}

\section{Graph 13 Croatia}

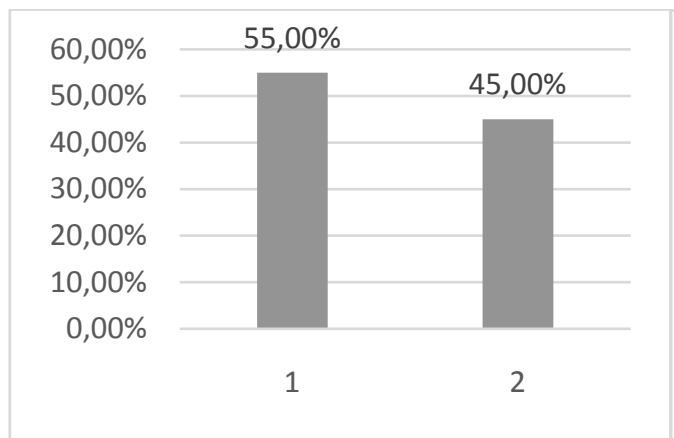

Graph 14 Austria

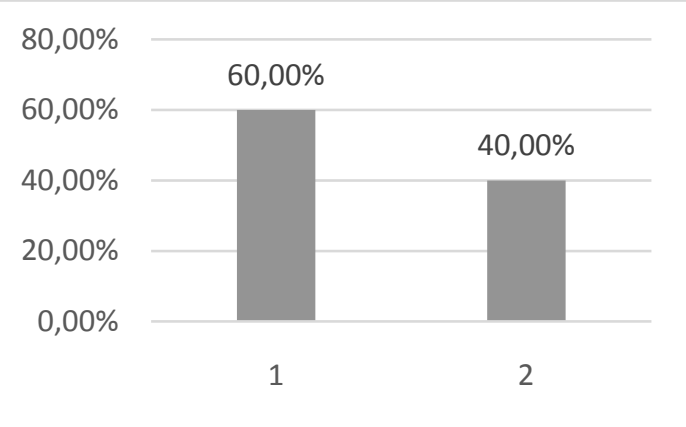

Note: 1 - Male 2 - Female

Source: Authors

In Croatia (Graph 15) there are $37.5 \%$ of respondents who have intercultural business contacts once a month and $20 \%$ of them only a few times in a month. There are $10 \%$ who contact foreign partners once a week. Only $32.5 \%$ of Croatian respondents engage in intercultural business communication on a daily basis while Austrian respondents (Graph 16) are involved in intercultural business interactions twice as often, i.e. $66.7 \%$ have daily contacts. There are $20 \%$ of Austrians who communicate interculturally once a month and only $6.7 \%$ a few times a month while $6.6 \%$ do it once a week.

\section{Graphs 15 and 16 Frequency of intercultural business interactions}

Graph 15 Croatia

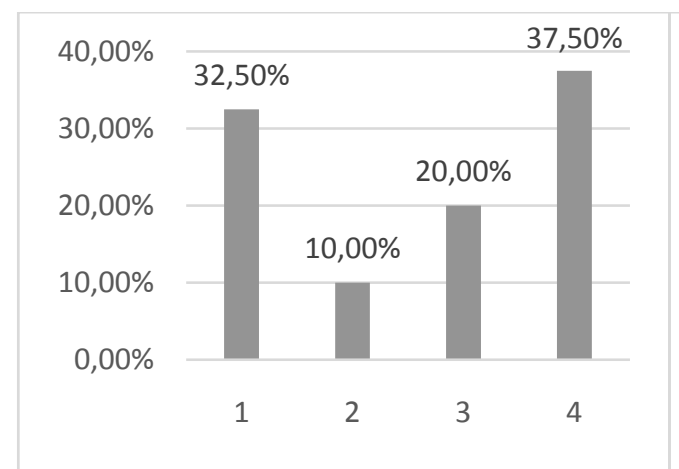

Graph 16 Austria

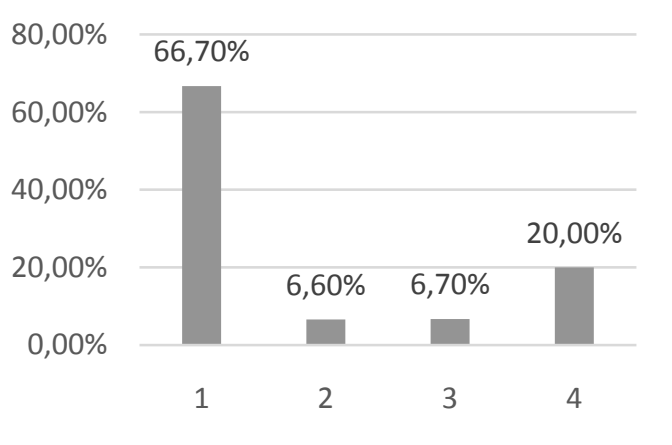

Note: 1 - Daily 2 - Twice a week 3 - A few times a month 4 - Once a month

Source: Authors 


\section{Graphs 17 and 18 Most common cultural barrier in intercultural business communication}

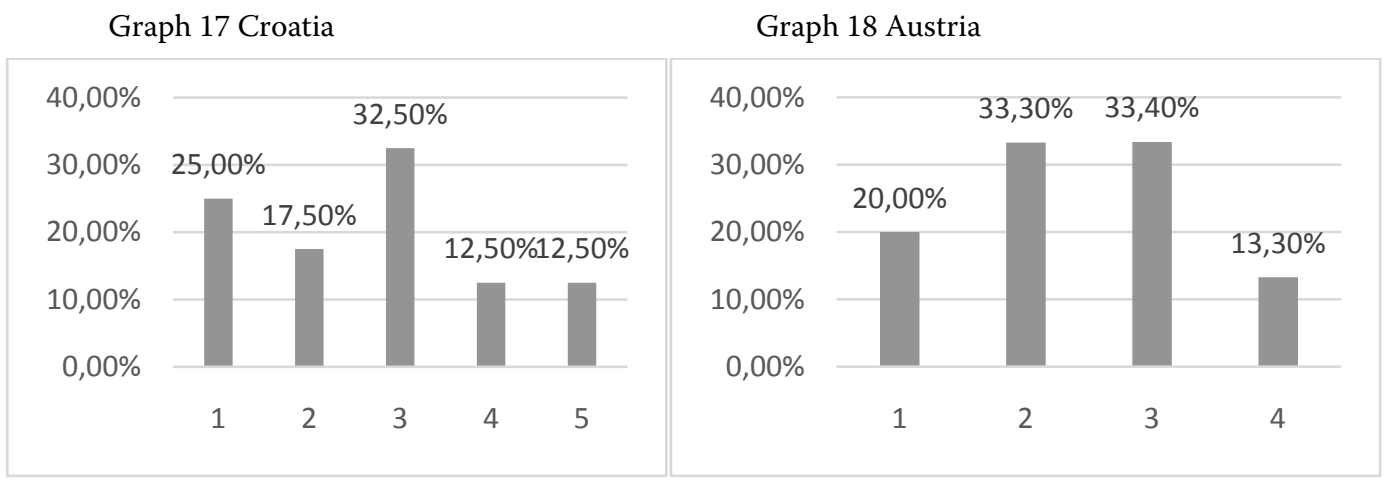

Note: 1 - Prejudice 2 - Language 3 - Could not decide (more than one selected barrier) 4 - Other (Croatia- ignorance of customs) 5 - Croatia - stereotypes

Source: Authors

When the respondents were to answer about their opinion and experience about the most common barriers in intercultural business communication, they show very different results. Very similar percentage of respondents, $32.5 \%$ of Croatians (Graph 17) and $33.4 \%$ of Austrians (Graph 18), could not decide on the one most common barrier and selected more than one. Austrians think that language is the most common cultural barrier in greater percentage (33.3\%) than Croatians (17.5\%). A similar percentage (25\% Croatians and 20\% Austrians) of respondents finds prejudice as the most common barrier in intercultural business communication. Austrians do not think stereotypes are the issue in intercultural interactions, while $12.5 \%$ of Croatian respondents find it as the most common barrier. Other barriers that were not suggested in the questionnaire were selected by $33.4 \%$ of Austrians but were so different that none could be isolated as important while $12.5 \%$ of Croatians state some other barriers and ignorance of customs appeared several times in their answers.

\section{Discussion}

Graphs 3 and 4 show that both cultures, Croatian and Austrian, gave similar results and, in the largest percentage, respondents believe that prior to business cooperation with a culturally different partner, these differences should be identified and studied. On the other hand, when checking the level of feeling offended if the other party does not adapt to the respondents' culture, a total of $15 \%$ of respondents in Croatia find it offensive, while the total percentage of Austrians who completely or partially agree is as high as $33.3 \%$.

According to the literature we have consulted, using titles within the Austrian culture is important. However, this research shows that as many as $40 \%$ of Austrians, which is also the largest share of respondents, rarely use titles. On the other hand, compared to Croatian culture, where $20 \%$ of respondents often use titles, in Austria it is only 6.7\%. The number of respondents who expressed intolerance to being late at business meetings (Croatia 52.5\% and Austria 53.3\%) suggests that both cultures are equally intolerant of late arrivals, although Austrians are less tolerant as they may accept the delay to a lesser extent, while in Croatia there is a certain percentage of respondents who tolerate delays of up to 30 minutes.

From all the above it can be concluded that the two cultures show relatively similar characteristics in terms of business formality, that is, they are significantly more similar than originally expected. Nonetheless, given the small differences that arise from this primary research and the research limitations, which mostly relate to a small sample and checking only part of the variables that relate to formalities in business communication, and in accordance with the results of secondary research, it can be concluded that the first hypothesis that reads: 'Austria is less tolerant of informality and relaxed attitudes in business than Croatia (e.g. late arrivals to meetings, ignorance of the customs of other cultures, etc.)' is accepted. It should be noted, however, that it needs 
to be much more thoroughly investigated on a more significant sample.

The question about the extent to which cultural differences affect business relationships provides information about the respondents' awareness of the issue and gives insight into the respondents' level of cultural intelligence. While an equal percentage of respondents from both cultures find that differences do not affect business performance in intercultural management and business, a significantly larger percentage of them in Croatia find it to have an impact compared to respondents in Austria. The frequency of intercultural contacts makes a significant difference, especially on a daily basis, where Austrians record twice the frequency of intercultural business meetings. The results show that there is also a difference in attitude towards barriers in intercultural communication and it can be concluded that the second hypothesis 'Croatians have less contact with people from different cultures than Austrians because Austria is more heterogeneous than Croatia and for that reason Austrians adapt to other cultures more easily' can be confirmed.

The frequency of women respondents in relation to men was smaller. The same can be observed in both groups of respondents. A smaller difference was recorded in determining the position on women's reliability in business, with $100 \%$ of Austrians confirming gender equality, and in Croatia this was the case with $92.5 \%$ of respondents. However, given the statistical significance of the percentage, it can be concluded that the third hypothesis 'Croatians as well as Austrians find no difference in the reliability of women in business compared with men' can be accepted.

\section{Conclusion}

Today's basis of international business is knowledge of language and culture. Due to cultural differences, or ignorance of them, there is additional noise within the communication process, leading to communication misunderstanding or even conflict that has nothing to do with the language barrier. There- fore, the focus on culture in the broadest sense and intercultural differences is a feature of modern multicultural business society. This paper presents the results of only a preliminary research; nevertheless, it gives an important insight into the theory of intercultural communication. The stated question was to find out which cultural indicators can have an impact on business communication outcome. This preliminary research gives a partial answer presenting three indicators (formality, experience, gender equity) that can be used as the starting point for future research. Of course, there is a need of determining other indicators that have an impact.

The preseneted theory shows the importance of being aware of the features of one's own culture and differences to others to be able to adapt accordingly to achieve successful intercultural communication. The theory has also showed that these differences have beed very precisly determined for and by developed and economically strong societies. This paper highlights the importance of continual observation of Croatian culture and putting it in correlation with other cultures, as Hofstede envisaged, with the aim of facilitating intercultural communication and ensuring that the desired communication outcomes are achieved. The secondary research shows there is not much information on Croatian culture indicators, and thus there is a huge area that should be investigated and many questions to be answered.

Although the discussion concluded with the acceptance of all three hypotheses, it should be taken into consideration that intercultural research is particularly demanding and that the sample of this research is relatively small. As such, this research constitutes only a guideline for future major studies that would be conducted in the context of Croatia's position in Europe and in the world. These major studies would be important to obtain and implement primary indicators that would lead to the promotion of cultural awareness and thus to raising the level of cultural intelligence in Croatia. In this way, the scientific basis would be gained from the great influence on the development of intercultural management and the international economy of Croatia. 


\section{REFERENCES}

1. Bedeković, V. (2010). Interkulturalni aspekti menadžmenta. Virovitica College.

2. Bedeković, V. \& Golub, D. (2011). Suvremeni menadžment u uvjetima globalnog poslovanja. Virovitica College.

3. Čerepinko, D. (2012). Komunikologija. Polytechnic of Varaždin.

4. Edwards, J. (1985). Language, Society and Identity. Basil Blackwell.

5. Hofstede, G. (1980). Culture's Consequences; International Differences in Work-Related Values. Sage. https://journals.sagepub.com/doi/10.1177/017084068300400409

6. Jariya, A. I. (2012). Western cultural values and its implications on management practices. South East Asian Journal of Contemporary Business, Economics and Law, 1, 61-70.

7. Kroeber, A. L., Kluckhohn, C. (1952). Culture: A Critical Review of Concepts and Definitions. Peabody Museum of American Archaeology \& Ethnology, Harvard University.

8. Kumbier, D. \& von Thun, F. S. (2009). Interkulturalna komunikacija: Metode, modeli, primjeri. Erudita.

9. Lewicki, R. J., Saunders, D. M. \& Barry, B. (2006). Pregovaranje. MATE.

10. Mesić, M. (2006). Multikulturalizam: društveni i teorijski izazovi. Školska knjiga.

11. Mikolić, M. (2002). Diplomatski i poslovni protokol. Barbat.

12. Osredečki, E. (2007). Poslovno komuniciranje i poslovni bonton. Edo.

13. Oyserman, D., Coon, H. M. \& Kemmelmeier, M. (2002). Rethinking individualism and collectivism: Evaluation of theoretical assumptions and meta-analyses. Psychological Bulletin, 128(1), 3-72. https://doi.org/10.1037/0033-2909.128.1.3

14. Perlitz, M. \& Seger, F. (2004). European cultures and management styles. International Journal of Asian Management, 3(1), 1-26. https://doi.org/10.1007/s10276-004-0016-y

15. Poslovni savjetnik (2006). Putovanje jednog managera. http://www.poslovni-savjetnik.com/sites/ default/files/PS\%2025.pdf

16. Rahimić, Z. \& Podrug, N. (2012). Medunarodni menadžment. School of Economics and Business Sarajevo.

17. Rammer, V. (2016). An Analysis of Different Cultures and Their Impact on Exchange Students. A Comparative Study of Austria and Sweden. In Überwimmer, M. et al. (Eds.). Proceedings of the Cross Cultural Business Conference 2016 (pp. 202-210). Steyr.

18. Samovar, L. A., Porter, R. E. \& McDaniel, E. R. (2013). Komunikacija izmedu kultura. Naklada Slap.

19. Schneider-Flaig, S. (2010). Veliki suvremeni bonton. Mozaik knjiga.

20. Tomljenović, Lj. \& Stilin, A. (2012). Istraživanje Hofstedeovih kulturalnih dimenzija na uzorku studenata poduzetništva. In Katalinić, B. (Ed.). Proceedings of the 3rd International Conference "Vallis Aurea focus on: Regional Development" (pp. 1031-1035). Požega: Polytechnic of Požega; Croatia \& DAAAM International Vienna.

21. Zakić, K. \& Milutinović, O. (2013). Doprinos interkulturalnog menadžmenta razvijanju tolerantnosti u međunarodnom poslovanju. Anali poslovne ekonomije, 5(9), 162-177. 